\title{
PENGARUH STORE ATMOSPHERE, IKLAN, DAN WORD OF MOUTH TERHADAP MINAT PEMBELIAN ULANG PELANGGAN PADA KFC DI MARGONDA, DEPOK
}

\author{
Silvia Hanisa ${ }^{1}$ \\ Resti Hardini ${ }^{2}$ \\ ${ }^{1,2}$ Fakultas Ekonomi dan Bisnis Universitas Nasional \\ Email: $\underline{\text { silviahanisa12345@gmail.com }}{ }^{1}$, resti.hardini@ yahoo.com ${ }^{2}$
}

\begin{abstract}
ABSTRAK
Penelitian ini bertujuan untuk menganalisis pengaruh store atmosphere, iklan, dan word of mouth terhadap minat pembelian ulang pelanggan pada KFC di Margonda, Depok. Penelitian ini menggunakan data primer yang diperoleh dari penyebaran kuesioner kepada 100 orang pelanggan KFC di Margonda, Depok yang diolah dengan metode regresi linear berganda. Hasil penelitian menunjukkan bahwa store atmosphere, iklan, dan word of mouth secara parsial berpengaruh positif dan signifikan terhadap minat pembelian ulang pelanggan pada KFC di Margonda, Depok.
\end{abstract}

Kata kunci: Store atmosphere, iklan, word of mouth, minat pembelian ulang

\section{ABSTRACT}

This study aims to analyze the influence of store atmosphere, advertising, and word of mouth on the customer's repurchase intention of KFC in Margonda, Depok. This study uses primary data obtained from the distribution of questionnaires to $100 \mathrm{KFC}$ customers in Margonda, Depok which will be processed by with multiple linear regression method. The results of this study show that store atmosphere, advertising, and word of mouth partially have positive and significant effect on the customer's repurchase intention of KFC in Margonda, Depok.

Keywords: Store atmosphere, advertising, word of mouth, repurchase intention

\section{PENDAHULUAN}

Dewasa ini, hampir semua orang membutuhkan hal yang serba instan karena aktivitas masyarakat yang begitu padat. Hal tersebut membuat sebagian masyarakat cenderung untuk memilih produk instan, seperti makanan cepat saji atau yang sering dikenal sebagai fast food untuk memenuhi kebutuhan primernya. Hal ini juga merupakan suatu peluang besar yang cukup menjanjikan bagi para pelaku bisnis. Salah satu contoh perusahaan yang memanfaatkan peluang tersebut adalah PT Fastfood Indonesia Tbk atau yang sering kita kenal sebagai KFC. KFC merupakan waralaba yang bergerak di bidang makanan yang sukses di Indonesia dan merupakan restoran dengan produk unggulan fried chicken yang paling populer di Indonesia. Berbagai macam varian chicken serta keunggulan produk telah ditawarkan oleh KFC yang menjadikannya sebagai pemimpin kategori produk fried chicken di Indonesia. 
KFC mempunyai beberapa cabang di berbagai kota di Indonesia, salah satunya adalah yang berada di daerah Margonda, Depok. Margonda, Depok merupakan tempat yang mempunyai banyak kuliner makanan, terutama yang berjenis fast food. Kompetitor utama KFC di daerah Margonda Depok antara lain McDonald, A \&W, Hoka Hoka Bento, CFC, Richesse Factory, Wendy's, dan berbagai merek fried chicken lainnya. Hal tesebut membuat konsumen memiliki beragam pertimbangan dalam memilih produk dari restoran mana yang akan dikonsumsinya. Perkembangan industri restoran cepat saji yang pesat ini menimbulkan persaingan yang sangat kompetitif. Oleh karena itu, setiap perusahaan berlomba-lomba untuk mendapatkan perhatian dari konsumen mengingat konsumen itu sendiri merupakan fokus utama kegiatan pemasaran yang menentukan keberhasilan dari setiap produk atau layanan di suatu perusahaan.

\section{Tabel 1. Top Brand Index Kategori Fast Food}

Periode 2013-2017

\begin{tabular}{|l|r|r|r|r|r|}
\hline \multicolumn{1}{|c|}{ Merek } & $\mathbf{2 0 1 3}$ & $\mathbf{2 0 1 4}$ & $\mathbf{2 0 1 5}$ & $\mathbf{2 0 1 6}$ & $\mathbf{2 0 1 7}$ \\
\hline KFC & $61,6 \%$ & $60,9 \%$ & $59,3 \%$ & $63,9 \%$ & $60,4 \%$ \\
\hline MCD & $17,3 \%$ & $17,5 \%$ & $17,5 \%$ & $18,6 \%$ & $19,0 \%$ \\
\hline A \& W & $6,8 \%$ & $6,7 \%$ & $7,1 \%$ & $2,6 \%$ & $3,7 \%$ \\
\hline Hokben & $3,8 \%$ & $5,1 \%$ & $4.1 \%$ & $2,5 \%$ & $2,9 \%$ \\
\hline CFC & $1,9 \%$ & $2,1 \%$ & - & $2,0 \%$ & $2,7 \%$ \\
\hline
\end{tabular}

(Sumber: Top Brand Award, 2019)

Berdasarkan tabel 1 di atas, top brand index KFC selama periode 2013-2017 senantiasa berada di peringkat pertama. Akan tetapi, KFC mengalami fluktuasi indeks yang bahkan cenderung menurun, yakni dari sebesar 61,6\% di tahun 2013 turun menjadi sebesar $60,4 \%$ di tahun 2017. Selain itu, rilis data yang ditampilkan pada https://www.kfcku.com juga menunjukkan bahwa KFC Margonda, Depok mengalami kecenderungan laba penjualan yang menurun selama lima tahun tersebut. Kedua indikasi di atas dapat mencerminkan adanya kecenderungan penurunan minat pembelian ulang (repurchase intention) pada KFC, khususnya dalam hal ini pada outlet yang berada di Margonda, Depok. Penurunan minat pembelian ulang ini antara lain dapat dipengaruhi oleh beberapa faktor, seperti store atmosphere, iklan, dan word of mouth.

Menurut Kotler dan Keller (2013:69), store atmosphere adalah suasana terencana yang sesuai dengan pasar sasarannya yang dapat menarik pelanggan untuk membeli. Store atmosphere yang baik, aman, dan nyaman akan menimbulkan persepsi positif bagi konsumen yang mendorongnya untuk menumbuhkan minat untuk melakukan pembelian ulang di tempat yang sama. Dengan demikian, perusahaan harus senantiasa mengusahakan 
agar store atmosphere sesuai dengan apa yang diekspektasikan oleh konsumen, sehingga mereka merasa puas dan nyaman atas atmosfer yang dirasakannya. Hal ini sesuai dengan hasil penelitian yang dilakukan oleh Azhari dan Rubiyanti (2016) yang menunjukkan bahwa minat pembelian ulang secara positif dan signifikan dipengaruhi oleh store atmosphere yang mencakup exterior, general interior, dan interior display.

Iklan juga dapat mempengaruhi minat pembelian ulang. Iklan itu sendiri merupakan pesan yang disampaikan oleh pengiklan tentang produk mereka kepada khalayak atau calon konsumen melalui media massa dengan tujuan untuk memberikan informasi serta membujuk dan mempengaruhi calon konsumen agar bertindak sesuai keinginan pengiklan. Dalam hal ini, keinginan yang dimaksud oleh pengiklan adalah keinginan agar konsumen memilih untuk membeli dan menggunakan produk yang diiklankan. Semakin sering iklan ditayangkan, maka semakin besar kemungkinan konsumen untuk tertarik melakukan pembelian dan pembelian ulang. Selain itu, semakin menarik iklan yang ditayangkan, maka semakin besar pula kemungkinan konsumen untuk tertarik melakukan pembelian dan pembelian ulang. Hal ini sesuai dengan hasil penelitian yang dilakukan oleh Andita (2017) yang menunjukkan bahwa minat pembelian ulang secara positif dan signifikan dipengaruhi oleh iklan.

Selain store atmosphere dan iklan, minat pembelian ulang juga dapat dipengaruhi oleh word of mouth. Word of mouth itu sendiri merupakan sebuah strategi pemasaran yang digunakan untuk membuat pelanggan membicarakan (do the talking), mempromosikan (do the promotion), dan menjual produk (do the selling) atau yang biasa disingkat menjadi TAPS, yakni Talking, Promoting dan Selling (Hidayati dkk., 2013). Monroe (1990) mengungkapkan bahwa minat pembelian ulang akan meningkatkan keinginan pelanggan untuk melakukan pembelian kembali yang dipicu oleh kepuasan atas produk yang ditawarkan perusahaan. Kepuasan itu sendiri dapat dicerminkan dari banyaknya word of mouth positif yang disebarkan oleh konsumen yang bersangkutan, sehingga word of mouth itu dinilai berkaitan erat dengan minat pembelian ulang. Hal ini sesuai dengan hasil penelitian yang dilakukan oleh Ismasari dan Farida (2016) yang menunjukkan bahwa minat pembelian ulang secara positif dan signifikan dipengaruhi oleh word of mouth.

Berdasarkan latar belakang yang telah diuraikan di atas, perlu dilakukan penelitian untuk menganalisis pengaruh store atmosphere, iklan, dan word of mouth terhadap minat pembelian ulang pelanggan di KFC, yang dalam hal ini difokuskan pada outlet yang berada di Margonda, Depok. Hasil analisis ini kemudian diharapkan dapat digunakan 
sebagai alat untuk meningkatkan minat pembelian ulang dan realisasinya, sehingga pada akhirnya dapat meningkatkan keputusan pembelian pelanggan serta laba outlet sekaligus perusahaan yang dimaksud.

\section{TINJAUAN PUSTAKA}

\section{Minat Pembelian Ulang}

Monroe (1990) dalam Sari dan Lestari (2019) mengartikan minat pembelian ulang (repurchase intention) sebagai suatu keinginan untuk kembali membeli suatu produk/jasa karena kepuasan yang diperoleh dari produk/jasa tersebut. Menurut Kinnear dan Taylor (1995), minat pembelian ulang merupakan niat untuk melakukan pembelian kembali pada kesempatan mendatang. Adapun Kusdyah (2012) mengartikan minat pembelian kembali sebagai bagian dari perilaku pembelian konsumen dimana kesesuaian antara performa dari produk atau jasa yang ditawarkan perusahaan menghasilkan minat konsumen untuk mengkonsumsinya lagi di masa yang akan datang.

Menurut Kotler dan Keller (2013), ada beberapa faktor utama yang mempengaruhi minat seseorang untuk melakukan pembelian ulang, yaitu faktor psikologis, faktor pribadi, dan faktor sosial. Minat pembelian ulang itu sendiri oleh Hawkins et al. (2007) dapat diidentifikasi melalui: (1) pembelian kembali produk di masa yang akan datang; (2) kengganan untuk berpindah ke merek lain; dan (3) pengurangan pencarian informasi sebelum membeli kembali.

\section{Store Athmosphere}

Store atmosphere merupakan karakteristik fisik toko yang dapat menunjukkan image (pesan) toko dan menarik konsumen (Berman dan Evan, 2012:36). Levy dan Weitz (2012) mendefinisikan store atmosphere sebagai desaian lingkungan melalui komunikasi visual, pencahayaan, warna, musik, dan wangi-wangian untuk menstimulasi persepsi dan respon emosional pelanggan dan akhirnya mempengaruhi perilaku pelanggan dalam membeli barang. Menurut Gillbert (2013:129), store atmosphere merupakan kombinasi dari pesan secara fisik yang telah direncanakan.

Lamb, Hair, dan McDAniel (2012:108) mengemukakan bahwa terdapat beberapa faktor yang berpengaruh dalam menciptakan store atmosphere, yaitu jenis karyawan, jenis barang dagangan dan kepadatannya, jenis perlengkapan tetap dan kepadatannya, bunyi suara, aroma, dan faktor visual. Menurut Berman dan Evan (2012:604), store atmosphere 
dapat dibagi ke dalam empat elemen, yaitu interior (bagian dalam toko), eksterior (bagian luar toko), store layout (tata letak), dan interior display.

\section{Iklan}

Kotler dan Armstrong (2012:454) mendefinisikan iklan sebagai segala bentuk penyajian dan promosi ide, barang atau jasa secara nonpersonal oleh suatu sponsor tertentu yang memerlukan pembayaran. Menurut Kasali (2007), iklan merupakan pesan yang menawarkan suatu produk yang ditujukan kepada masyarakat lewat suatu media. Tjiptono (2011:41) berpendapat bahwa iklan memiliki tiga tujuan utama, yaitu menginformasikan produk yang ditawarkan dan menciptakan permintaan awal, membujuk dan mempengaruhi konsumen untuk membeli produk yang ditawarkan, serta mengingatkan konsumen mengenai keberadaan suatu produk serta berupaya melekatkan nama atau merek produk tertentu di benak konsumen.

Menurut Tjiptono (2011:227), iklan mempunyai sifat-sifat sebagai berikut:

1. Public presentation, yakni memungkinkan setiap orang untuk menerima pesan yang sama tentang produk yang diiklankan.

2. Persuasiveness, yakni ditujukan untuk memantapkan penerimaan informasi.

3. Amplifed Expresiveness, yakni mampu mendramatisasi perusahaan dan produknya melalui gambar dan suara untuk menggugah dan mempengaruhi perasaan khalayak.

4. Impersonality, yakni tidak bersifat memaksa khalayak untuk memperhatikan dan menanggapinya karena merupakan komunikasi yang menolong (satu arah).

\section{Word of Mouth}

Kotler dan Keller (2013) mendefinisikan komunikasi dari mulut ke mulut (word of mouth communication / WOM) sebagai suatu proses komunikasi yang berupa pemberian rekomendasi, baik secara individu maupun kelompok, terhadap suatu produk atau jasa yang bertujuan untuk memberikan informasi secara personal. Menurut Hasan (2014:15), model word of mouth marketing merupakan suatu upaya mengantarkan dan menyampaikan pesan bisnis kepada orang lain, keluarga, teman, dan mitra bisnis, khususnya target pasar (offline), agar mereka dapat mengetahui keunggulan produk di tengah tawaran produk saingan yang semakin beragam.

Seringkali pemasar mendorong word of mouth oleh konsumen perihal suatu promosi untuk membantu menyebarkan kesadaran di luar konsumen yang mulai 
berinteraksi langsung dengan promosi tersebut. Dalam hal ini, konsumen berbagi informasi dengan teman mengenai penawaran menarik untuk produk tertentu (Peter dan Olson, 2014). Menurut Hasan (2010:25), word of mouth dapat menjadi informasi yang kuat karena merupakan sumber informasi yang independen dan jujur, sehingga lebih kredibel karena tidak ada keterkaitan antara orang yang melakukan word of mouth dengan perusahaan yang memproduksi atau memperjualbelikan produk.

\section{Keterkaitan Antarvariabel Penelitian}

\section{Keterkaitan antara Store Atmosphere dan Minat Pembelian Ulang}

Berdasarkan definisi yang dikemukakan oleh Levy dan Weitz (2012), store atmosphere ditujukan untuk menstimulasi persepsi dan respon emosional pelanggan hingga akhirnya mempengaruhi perilaku pelanggan dalam membeli barang. Kotler dan Keller (2013) menambahkan bahwa store atmosphere didesain suasana dengan pasar sasaran sehingga dapat menarik pelanggan untuk melakukan pembelian. Store atmosphere yang baik, aman, dan nyaman akan menimbulkan persepsi positif bagi konsumen yang mendorongnya untuk menumbuhkan minat untuk melakukan pembelian ulang di tempat yang sama. Dengan demikian, perusahaan harus senantiasa mengusahakan agar store atmosphere sesuai dengan apa yang diekspektasikan oleh konsumen, sehingga mereka merasa puas dan nyaman atas atmosfer yang dirasakannya. Hal ini sesuai dengan hasil penelitian yang dilakukan oleh Azhari dan Rubiyanti (2016) yang menunjukkan bahwa minat pembelian ulang secara positif dan signifikan dipengaruhi oleh store atmosphere yang mencakup exterior, general interior, dan interior display.

$\mathrm{H}_{1}$ : $\quad$ Store atmosphere berpengaruh positif dan signifikan terhadap minat pembelian pelanggan pada KFC di Margonda, Depok.

\section{Keterkaitan antara Iklan dan Minat Pembelian Ulang}

Iklan juga dapat mempengaruhi minat pembelian ulang. Iklan itu sendiri merupakan pesan yang disampaikan oleh pengiklan tentang produk mereka kepada khalayak atau calon konsumen melalui media massa dengan tujuan untuk memberikan informasi serta membujuk dan mempengaruhi calon konsumen agar bertindak sesuai keinginan pengiklan. Dalam hal ini, keinginan yang dimaksud oleh pengiklan adalah keinginan agar konsumen memilih untuk membeli dan menggunakan produk yang diiklankan. Semakin sering iklan ditayangkan, maka semakin besar kemungkinan 
konsumen untuk tertarik melakukan pembelian dan pembelian ulang. Selain itu, semakin menarik iklan yang ditayangkan, maka semakin besar pula kemungkinan konsumen untuk tertarik melakukan pembelian dan pembelian ulang. Hal ini sesuai dengan hasil penelitian yang dilakukan oleh Andita (2017) yang menunjukkan bahwa minat pembelian ulang secara positif dan signifikan dipengaruhi oleh iklan.

$\mathrm{H}_{2}$ : Iklan berpengaruh positif dan signifikan terhadap minat pembelian pelanggan pada KFC di Margonda, Depok.

\section{Keterkaitan antara Word of Mouth dan Minat Pembelian Ulang}

Word of mouth dinilai memiliki keterkaitan erat dengan minat pembelian ulang. Monroe (1990) mengungkapkan bahwa minat pembelian ulang akan meningkatkan keinginan pelanggan untuk melakukan pembelian kembali yang dipicu oleh kepuasan atas produk yang ditawarkan perusahaan. Kepuasan itu sendiri dapat dicerminkan dari banyaknya word of mouth positif yang disebarkan oleh konsumen yang bersangkutan, sehingga word of mouth dinilai berkaitan erat dengan minat pembelian ulang. Word of mouth efektif dalam meningkatkan minat seorang pengguna dalam menggunakan kembali produk karena kata-kata dari seorang teman, saudara, ataupun orang tua dianggap lebih kredibel dibandingkan dengan promosi dan keterangan yang ada dalam suatu produk karena berasal dari sumber informasi yang independen dan jujur mengingat tidak ada keterkaitan antara orang yang melakukan word of mouth dengan perusahaan yang memproduksi atau memperjualbelikan produk. Hal ini sesuai dengan hasil penelitian yang dilakukan oleh Ismasari dan Farida (2016) yang menunjukkan bahwa minat pembelian ulang secara positif dan signifikan dipengaruhi oleh word of mouth.

$\mathrm{H}_{3}$ : Word of mouth berpengaruh positif dan signifikan terhadap minat pembelian pelanggan pada KFC di Margonda, Depok.

\section{Kerangka Pemikiran}

Kerangka pemikiran yang digunakan dalam penelitian ini dapat dilihat sebagai berikut. 


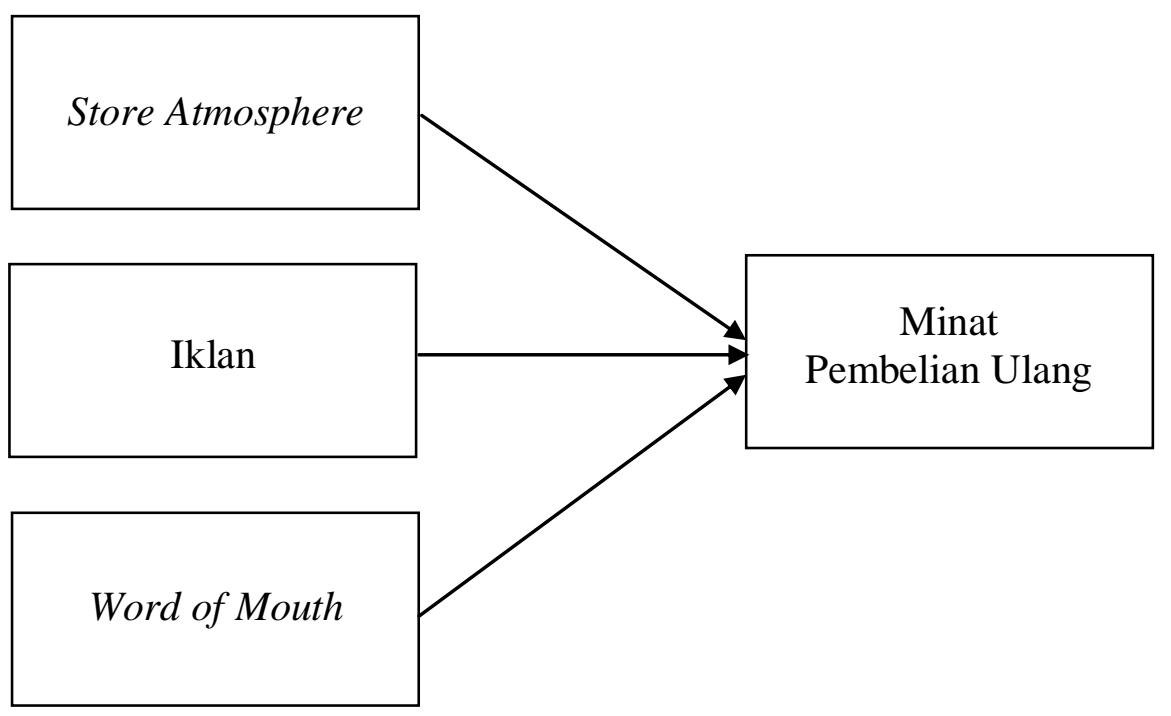

Gambar 1. Kerangka Pemikiran

\section{METODOLOGI PENELITIAN}

\section{Jenis dan Sumber Data}

Penelitian ini menggunakan data primer berjenis cross section yang diperoleh dari penyebaran kuesioner kepada responden yang dijadikan sebagai sampel penelitian.

\section{Populasi dan Sampel}

Penelitian ini menggunakan populasi berupa para pelanggan di KFC Margonda, Depok. Oleh karena jumlah populasi yang tidak diketahui, maka penentuan jumlah sampel dilakukan dengan menggunakan rumus William. Dengan rumus tersebut, jumlah sampel yang digunakan dalam penelitian ini adalah 100 responden.

\section{Metode Analisis}

Metode analisis inferensial yang digunakan dalam penelitian ini adalah metode analisis regresi linear berganda yang ditujukan untuk menganalisis pengaruh store atmosphere, iklan, dan word of mouth terhadap minat pembelian ulang pelanggan pada KFC di Margonda, Depok. 


\section{HASIL DAN PEMBAHASAN}

\section{Hasil Penelitian}

\section{Hasil Uji Instrumen}

Uji instrumen yang dilakukan dalam penelitian ini terdiri dari uji validitas dan reliabilitas. Hasil uji validitas menunjukkan bahwa masing-masing item pernyataan dari setiap variabel memiliki nilai corected item-total atau $r$ hitung yang lebih besar daripada nilai $r$ tabel $(0,196)$. Dengan demikian, seluruh item pernyataan yang digunakan dalam penelitian dinyatakan valid. Adapun hasil uji reliabilitas menunjukkan bahwa setiap variabel memiliki nilai cronbach alpha's yang lebih besar daripada 0,60, sehingga instrumen yang digunakan dalam setiap variabel penelitian ini dinyatakan reliabel.

\section{Hasil Uji Asumsi Klasik}

Uji asumsi klasik yang dilakukan dalam penelitian ini terdiri dari uji normalitas, uji autokorelasi, uji multikolinearitas, dan uji heteroskedastisitas. Hasil uji normalitas dengan menggunakan Kolmogorov - Smirnov Test menunjukkan adanya nilai asymp sig. (2-tailed) sebesar 0,200 yang berada di atas 0,05, sehingga dapat disimpulkan bahwa data terdistribusi normal dan layak untuk digunakan dalam model regresi. Adapun hasil uji autokorelasi dengan menggunakan Durbin-Watson Test menunjukkan nilai DW sebesar 2,018. Dengan sampel sebanyak $100(\mathrm{n}=100)$, maka diketahui nilai dU (batas atas) adalah sebesar 1,736 dan nilai dL (batas bawah) adalah sebesar 1,631. Oleh karena nilai DW sebesar 2,010 terletak diantara dU dan 4-dU $(1,736<2,010<2,263)$, maka dapat disimpulkan bahwa tidak terjadi autokorelasi dalam model regresi yang digunakan dalam penelitian ini.

Hasil uji multikolinearitas menunjukkan bahwa semua variabel independen, yaitu store atmosphere, iklan, dan word of mouth, memiliki nilai tolerance yang lebih besar daripada 0,1 dan nilai Variance Inflation Factor (VIF) yang lebih kecil daripada 10, sehingga terbukti tidak terdapat gejala multikolinearitas dalam model regresi ini. Dalam hal ini, nilai tolerance variabel store atmosphere, iklan, dan word of mouth secara berturutturut adalah $0,490,0,368$, dan 0,411, sementara nilai VIF-nya secara berturut-turut adalah 2,043, 2,718, dan 2,432. Adapun hasil uji heteroskedastisitas dengan menggunakan Glejser Test menunjukkan bahwa semua variabel mempunyai nilai signifikan yang lebih besar daripada 0,05 , sehingga terbukti bahwa tidak terjadi heteroskedastisitas pada model regresi yang digunakan dalam penelitian ini. 


\section{Hasil Uji Regresi Linear Berganda}

Hasil uji regresi linear berganda dapat dilihat pada tabel sebagai berikut.

Tabel 2. Hasil Uji Regresi Linear Berganda

\begin{tabular}{|l|c|c|c|c|c|}
\hline \multicolumn{7}{|c|}{ Coefficients $^{\mathbf{a}}$} \\
\hline \multirow{2}{*}{ Model } & \multicolumn{2}{|c|}{$\begin{array}{c}\text { Unstandardized } \\
\text { Coefficients }\end{array}$} & $\begin{array}{c}\text { Standardized } \\
\text { Coefficients }\end{array}$ & \multirow{2}{*}{ t } & \multirow{2}{*}{ Sig. } \\
\cline { 2 - 5 } & $\mathbf{B}$ & $\begin{array}{c}\text { Std. } \\
\text { Error }\end{array}$ & Beta & & \\
\hline (Constant) & 0,791 & 1,369 & & 0,578 & 0,565 \\
\hline Store atmosphere & 0,173 & 0,084 & 0,168 & 2,066 & 0,041 \\
\hline Iklan & 0,383 & 0,090 & 0,400 & 4,266 & 0,000 \\
\hline Word of mouth & 0,366 & 0,092 & 0,351 & 3,957 & 0,000 \\
\hline
\end{tabular}

(Sumber: Data diolah, 2019)

Berdasarkan hasil uji regresi berganda, diperoleh model persamaan sebagai berikut.

$$
Y=0,168 X_{1}+0,400 X_{2}+0,351 X_{3}
$$

Keterangan:

$\mathrm{Y} \quad=$ Minat pembelian ulang

$X_{1}=$ Store atmosphere

$X_{2} \quad=$ Iklan

$X_{3} \quad=$ Word of mouth

\section{Hasil Uji Kelayakan Model}

Dari uji kelayakan model dengan ANOVA, diperoleh nilai F hitung sebesar 71,028 dengan tingkat signifikansi sebesar 0,000. Oleh karena $\mathrm{F}$ hitung $>\mathrm{F}$ tabel $(71,028>2,70)$ dan tingkat signifikansi $<0,05(0,000<0,005)$, maka dapat disimpulkan bahwa store atmosphere, iklan, dan word of mouth secara bersama-sama berpengaruh signifikan terhadap minat pembelian ulang pelanggan pada KFC di Margonda, Depok. Dengan nilai $R$ square (koefisien determinasi) sebesar 0,689, maka store atmosphere, iklan, dan word of mouth terbukti dapat memberikan kontribusi sebesar 68,9\% dalam mempengaruhi minat pembelian ulang, sementara $31,1 \%$ sisanya dijelaskan oleh variabel-variabel lain yang tidak dianalisis dalam penelitian ini. 


\section{Hasil Uji Hipotesis}

Berdasarkan hasil pengujian hipotesis terhadap model regresi yang digunakan sebagaimana yang disajikan dalam tabel 2, dapat dijelaskan hal-hal sebagai berikut.

a. Besarnya nilai $t_{\text {hitung }}$ pada variabel store atmosphere adalah 2,066 dengan nilai signifikan sebesar 0,041 , sehingga nilai $t_{\text {hitung }}>$ nilai $t_{\text {tabel }}(2,066>1,984)$ dan tingkat signifikan $<0,05(0,041<0,05)$. Hal tersebut menunjukkan bahwa $\mathrm{H}_{0}$ ditolak dan $\mathrm{H}_{\mathrm{a}}$ diterima, sehingga store atmosphere terbukti berpengaruh positif dan signifikan terhadap minat pembelian ulang pelanggan pada KFC di Margonda, Depok.

b. Besarnya nilai $t_{\text {hitung }}$ pada variabel iklan adalah 4,266 dengan nilai signifikan sebesar 0,000 , sehingga nilai $t_{\text {hitung }}>$ nilai $t_{\text {tabel }}(4,266>1,984)$ dan tingkat signifikan $<0,05(0,000<0,05)$. Hal tersebut menunjukkan bahwa $\mathrm{H}_{0}$ ditolak dan $\mathrm{H}_{\mathrm{a}}$ diterima, sehingga iklan terbukti berpengaruh positif dan signifikan terhadap minat pembelian ulang pelanggan pada KFC di Margonda, Depok.

c. Besarnya nilai $t_{\text {hitung }}$ pada variabel word of mouth adalah 3,957 dengan nilai signifikan sebesar 0,000 , sehingga nilai $t_{\text {hitung }}>$ nilai $t_{\text {tabel }}(3,957>1,984)$ dan tingkat signifikan $<0,05(0,000<0,05)$. Hal tersebut menunjukkan bahwa $\mathrm{H}_{0}$ ditolak dan $\mathrm{H}_{\mathrm{a}}$ diterima, sehingga word of mouth terbukti berpengaruh positif dan signifikan terhadap minat pembelian ulang pelanggan pada KFC di Margonda, Depok.

\section{Pembahasan}

\section{Pengaruh Store Atmosphere Produk terhadap Minat Pembelian Ulang}

Hasil pengujian hipotesis menunjukkan bahwa store atmosphere berpengaruh positif dan signifikan terhadap minat pembelian ulang pelanggan pada KFC di Margonda, Depok. Dengan kata lain, semakin baik store atmosphere pada outlet KFC di Margonda, Depok, maka akan semakin tinggi minat pembelian ulang pelanggan terhadapnya. Sebaliknya, semakin buruk store atmosphere pada outlet KFC di Margonda, Depok, maka akan semakin rendah minat pembelian ulang pelanggan terhadapnya. Hal ini sejalan dengan hasil penelitian yang dilakukan oleh Azhari dan Rubiyanti (2016) yang menunjukkan bahwa minat pembelian ulang secara positif dan signifikan dipengaruhi oleh store atmosphere yang mencakup exterior, general interior, dan interior display. 
Berdasarkan definisi yang dikemukakan oleh Levy dan Weitz (2012), store atmosphere ditujukan untuk menstimulasi persepsi dan respon emosional pelanggan hingga akhirnya mempengaruhi perilaku pelanggan dalam membeli barang. Kotler dan Keller (2013) menambahkan bahwa store atmosphere didesain suasana dengan pasar sasaran sehingga dapat menarik pelanggan untuk melakukan pembelian. Store atmosphere yang baik, aman, dan nyaman akan menimbulkan persepsi positif bagi konsumen yang mendorongnya untuk menumbuhkan minat untuk melakukan pembelian ulang di tempat yang sama. Dengan demikian, perusahaan harus senantiasa mengusahakan agar store atmosphere sesuai dengan apa yang diekspektasikan oleh konsumen, sehingga mereka merasa puas dan nyaman atas atmosfer yang dirasakannya.

\section{Pengaruh Iklan terhadap Minat Pembelian Ulang}

Hasil pengujian hipotesis menunjukkan bahwa iklan berpengaruh positif dan signifikan terhadap minat pembelian ulang pelanggan pada KFC di Margonda, Depok. Dengan kata lain, semakin baik dan menarik penyampaian pesan persuasif yang disampaikan oleh perusahaan melalui iklan, maka akan semakin tinggi minat pembelian ulang pelanggan terhadap produk yang ditawarkannya. Sebaliknya, semakin buruk dan tidak menarik pesan persuasif yang disampaikan oleh perusahaan melalui iklan, maka akan semakin rendah minat pembelian ulang pelanggan produk yang ditawarkannya. Hal ini sejalan dengan hasil penelitian yang dilakukan oleh Andita (2017) yang menunjukkan bahwa minat pembelian ulang secara positif dan signifikan dipengaruhi oleh iklan.

Iklan itu sendiri merupakan pesan yang disampaikan oleh pengiklan tentang produk mereka kepada khalayak atau calon konsumen melalui media massa dengan tujuan untuk memberikan informasi serta membujuk dan mempengaruhi calon konsumen agar bertindak sesuai keinginan pengiklan. Dalam hal ini, keinginan yang dimaksud oleh pengiklan adalah keinginan agar konsumen memilih untuk membeli dan menggunakan produk yang diiklankan. Semakin sering iklan ditayangkan, maka semakin besar kemungkinan konsumen untuk tertarik melakukan pembelian dan pembelian ulang. Selain itu, semakin menarik iklan yang ditayangkan, maka semakin besar pula kemungkinan konsumen untuk tertarik melakukan pembelian dan pembelian ulang. 


\section{Pengaruh Word of Mouth terhadap Minat Pembelian Ulang}

Hasil pengujian hipotesis menunjukkan bahwa word of mouth berpengaruh positif dan signifikan terhadap minat pembelian ulang pelanggan pada KFC di Margonda, Depok. Dengan kata lain, semakin baik word of mouth yang tersebar mengenai produk yang ditawarkan oleh perusahaan, maka akan semakin tinggi minat pembelian ulang pelanggan terhadap produk tersebut. Sebaliknya, semakin buruk word of mouth yang tersebar mengenai produk yang ditawarkan oleh perusahaan, maka akan semakin rendah minat pembelian ulang pelanggan produk tersebut. Hal ini sejalan dengan hasil penelitian yang dilakukan oleh Ismasari dan Farida (2016) yang menunjukkan bahwa minat pembelian ulang secara positif dan signifikan dipengaruhi oleh word of mouth.

Monroe (1990) mengungkapkan bahwa minat pembelian ulang akan meningkatkan keinginan pelanggan untuk melakukan pembelian kembali yang dipicu oleh kepuasan atas produk yang ditawarkan perusahaan. Kepuasan itu sendiri dapat dicerminkan dari banyaknya word of mouth positif yang disebarkan oleh konsumen yang bersangkutan, sehingga word of mouth dinilai berkaitan erat dengan minat pembelian ulang. Word of mouth efektif dalam meningkatkan minat seorang pengguna dalam menggunakan kembali produk karena kata-kata dari seorang teman, saudara, ataupun orang tua dianggap lebih kredibel dibandingkan dengan promosi dan keterangan yang ada dalam suatu produk karena berasal dari sumber informasi yang independen dan jujur mengingat tidak ada keterkaitan antara orang yang melakukan word of mouth dengan perusahaan yang memproduksi atau memperjualbelikan produk.

\section{KESIMPULAN DAN SARAN}

\section{Kesimpulan}

Berdasarkan hasil penelitian dan pembahasan, dapat ditarik kesimpulan bahwa store atmosphere, iklan, dan word of mouth secara parsial berpengaruh positif dan signifikan terhadap minat pembelian ulang pelanggan pada KFC di Margonda, Depok.

\section{Saran}

Berdasarkan kesimpulan di atas, maka saran yang dapat diberikan adalah sebagai berikut. 
1. Perusahaan diharapkan dapat meningkatkan minat pembelian ulang pelanggannya dengan menaruh perhatian yang lebih mendalam lagi pada store atmosphere outletnya sesuai dengan keinginan pelanggan, terutama dari segi desain warna outlet.

2. Perusahaan diharapkan dapat mempertahankan atau bahkan meningkatkan penyampaian pesan persuasif yang efektif melalui iklan untuk memudahkan pelanggan agar dalam mengingat kembali produk yang ditawarkan

3. Perusahaan diharapkan dapat mempertahankan atau bahkan meningkatkan strategi word of mouth yang baik untuk mempertahankan dan meningkatkan popularitas dan citra perusahaan yang pada akhirnya dapat secara positif mempengaruhi minat pembelian ulang pelanggan.

\section{DAFTAR PUSTAKA}

Andita, A.C. 2017. Pengaruh Iklan, Harga, dan Kualitas Produk terhadap Minat Beli Ulang Konsumen: Studi Kasus pada Mahasiswa Konsumen Isoplusi di Universitas Sanata Dharma. Skripsi. Fakultas Ekonomi Universitas Sanata Dharma. Yogyakarta.

Azhari, P.P. dan R.N. Rubiyanti. 2016. Pengaruh Store Atmosphere terhadap Minat Pembelian Ulang Konsumen pada Nom Nom Eatery Bandung. E-Proceeding of management. Universitas Telkom. 3(1): 512-516.

Berman, B. dan J.R. Evans. 2012. Retail Management: a Strategic Approach. $8^{\text {th }}$ Edition. Pearson Education. New Jersey.

Fadillah, F. dan H. Prabowo. 2014. Pengaruh Kualitas Pelayanan dan Citra Merek Terhadap Kepuasan Konsumen dan Dampaknya Terhadap Minat Beli Ulang Pada PT Diva Karoke. JP FEB UNSOED. 4(1): 216-227.

Hasan, A. 2014. Marketing dan Kasus-Kasus Pilihan. CAPS. Yogyakarta.

Hawkins, D.I., D.L. Motherbaugh, dan R.J. Best. 2007. Counsumer Behavior: Building Marketing Strategy. $10^{\text {th }}$ Edition. McGraw Hill. New York.

Hidayati, H.A., Suharyono, dan S. Kumadji. 2013. Faktor-Faktor yang Membentuk Komunikasi Word of Mouth dan Pengaruhnya terhadap Keputusan Pembelian: Studi pada Konsumen Ketan Legenda Batu. Jurnal Administrasi Bisnis. 6(1): 1-8.

Ismasari, R.A. dan N. Farida. 2016. Pengaruh Word of Mouth dan Brand Image terhadap Repurchase Intention Melalui Brand Trust Smartphone Samsung Galaxy Series. Journal of Management. Jurnal Ilmu Administrasi Bisnis. 5(4).

Peter, J.P. dan J.C. Olson. 2014. Counsumer Behavior and Marketing Strategy. Pearson Education. New Jersey. 
Kasali, R. 2007. Membidik Pasar Indonesia Segmentasi Targeting Positioning. PT Gramedia Pustaka Utama. Jakarta.

KFC Indonesia. 2019. https://www.kfcku.com. 15 Februari 2019 (11.05).

Kinnear, T.C. dan J.R. Taylor. 1995. Marketing Research: An Appllied Approach. McGraw Hill. New York.

Kotler, P. dan K. L. Keller. 2008. Marketing Management. $13^{\text {th }}$ Ed. Pearson Education. New Jersey. Terjemahan B. Sabran. 2013. Manajemen Pemasaran. Edisi 13. Erlangga. Jakarta.

dan G. Armstrong. 2007. Principle of Marketing. $12^{\text {th }}$ ed. Pearson Prentice Hall. Terjemahan B. Sabran. 2012. Prinsip-prinsip Pemasaran. Edisi 12. Erlangga. Jakarta.

Kusdyah, I. 2012. Persepsi Harga, Persepsi Merek, Persepsi Nilai, dan Keinginan Pembelian Ulang Jasa Clinic Kesehatan: Studi Kasus Erha Clinic Surabaya. Jurnal Manajemen Pemasaran. 7(1): 25-32.

Lamb, C.W., J.F. Hair, dan C. McDaniel. 2001. Marketing. Pearson Education. New Jersey. Terjemahan David Octarevia. 2012. Pemasaran. Salemba Empat. Jakarta.

Levy, M. dan B.A. Weitz. 2012. Retailing Management Information Center. McGraw Hill Higher Education. New York.

Monroe, K.B. 1990. Pricing: Making Profitable Decision McGrawHill. New York.

Sari, M.R. dan R. Lestari. 2019. Pengaruh Persepsi Harga, Kualitas Pelayanan, dan Kualitas Produk terhadap Kepuasan dan Dampaknya pada Minat Pembelian Ulang Konsumen Kereta Api Kelas Eksekutif Argo Parahyangan. Oikonomia: Jurnal Manajemen. 15(1): 30-44.

Tjiptono, F. 2011. Kualitas Jasa dan Kepuasan. Edisi Ketiga. Andi. Yogyakarta.

Top Brand Award. 2019. www.topbrand-award.com. 15 Februari 2019 (12.20). 